\title{
PHENYLBUTAZONE IN THE TREATMENT OF TIETZE'S SYNDROME
}

\author{
BY \\ ERKKI J. VALTONEN \\ Department of Physical Medicine, University Central \\ Hospital, Helsinki, Finland
}

Tietze's syndrome consists of an initially painful, usually tender prominence of one or more of the upper costal cartilages for which no specific aetiology can be found. Biopsy usually shows the cartilage to be normal. The clinical course is benign but may be prolonged.

The rather characteristic clinical picture suggests the diagnosis. Confirmation is largely a matter of exclusion, and involvement of the costal cartilage by systemic disease should be ruled out.

The chief complaint in the vast majority of reported cases was pain, although a few patients noted a swelling before the onset of pain; this was generally localized to the affected cartilage, but radiation laterally and even into the arm has been described (Düben, 1952; Pasquali, 1950). Onset can be sudden or gradual and the intensity of pain ranges from mild to severe. Exacerbation with coughing or deep breathing has been reported (Düben, 1952; Acharya, 1944).

The first report in the world literature of the condition which is now generally called Tietze's syndrome was made by Tietze (1921), who published four case histories. In a thorough review of the world literature, Kayser (1956) found 159 cases compatible with the clinical picture of Tietze's syndrome.
Because there is much disagreement on the proper treatment of this condition, the author's experience in a series of four cases treated with phenylbutazone are presented here (Table).

\section{Case Reports}

Case 1, A female telephone operator aged 40, had suffered for 5 months from intermittent pains over the upper sternum, radiating occasionally towards the right arm. The pain was exacerbated by work. She noticed a tender swelling, the size of a plum, on her chest. There was no history of trauma to the area.

Examination.-Nothing was found but a hard, fixed, tender, and fusiform swelling measuring approximately $3 \times 4 \mathrm{~cm}$. over the right third costal cartilage. There was no local inflammation or erythema. The overlying skin was freely movable and was neither ulcerated nor oedematous. $X$ rays of the chest were negative, the erythrocyte sedimentation rate was $7 \mathrm{~mm} . / 1 \mathrm{hr}$, and the leucocyte count 3,500 .

Treatment.-She had been treated with short-wave diathermy, physiotherapy, muscle relaxants, and topical injections with local anaesthetics, and a long-acting cortisone derivative (methyl-prednisolone), into the site of the swelling with no improvement.

$400 \mathrm{mg}$. phenylbutazone three times daily was prescribed, and 3 weeks later the swelling had clearly decreased; the patient had no more pain, and even severe exertion did not aggravate the condition.

TABLE

CLINICAL PARTICULARS OF FOUR CASES

\begin{tabular}{|c|c|c|c|c|c|c|}
\hline Case No. & Sex & $\begin{array}{c}\text { Age } \\
\text { (yrs) }\end{array}$ & $\begin{array}{l}\text { Duration of } \\
\text { Disease (yrs) }\end{array}$ & $\begin{array}{l}\text { Phenylbutazone } \\
\text { Therapy }\end{array}$ & $\begin{array}{l}\text { Duration of } \\
\text { Therapy (wks) }\end{array}$ & Result \\
\hline 1 & $\mathbf{F}$ & 40 & $5 / 12$ & $\begin{array}{l}400 \mathrm{mg} \text {. } \\
\text { three times daily }\end{array}$ & 3 & $\begin{array}{l}\text { Swelling decreased } \\
\text { Pain absent }\end{array}$ \\
\hline 2 & $\mathbf{F}$ & 57 & 6 & $\begin{array}{l}400 \mathrm{mg} \text {. } \\
\text { three times daily }\end{array}$ & 3 & $\begin{array}{l}\text { Swelling unchanged } \\
\text { Pain absent except on exertion }\end{array}$ \\
\hline 3 & $\mathbf{F}$ & 63 & $6 / 12$ & $\begin{array}{l}5 \text { per cent. ointment } \\
3 \text { or } 4 \text { times daily }\end{array}$ & 5 & $\begin{array}{l}\text { Swelling almost gone } \\
\text { Pain absent }\end{array}$ \\
\hline 4 & $\mathbf{M}$ & 41 & 1 & $\begin{array}{l}400 \mathrm{mg} . \\
\text { twice daily }\end{array}$ & 2 & $\begin{array}{l}\text { Swelling unchanged } \\
\text { Pain absent }\end{array}$ \\
\hline
\end{tabular}


Result.-The medication was discontinued but the pain and swelling did not re-appear.

Case 2, A female factory worker aged 57, had suffered for 6 years from almost uninterrupted pain over the left third costal cartilage, radiating along the ribs to the left. The pain was exacerbated by work and relieved by rest.

Examination.-There was a hard, very tender, round swelling measuring approximately $4 \times 4 \mathrm{~cm}$. over the left third costal cartilage. The overlying skin was freely movable and intact. $X$ rays of the chest were negative, and the erythrocyte sedimentation rate and leucocyte count were normal.

Treatment.-The patient had tried numerous drugs but with no improvement. Methylprednisolone was twice injected into the site of the swelling but there was no response, and a course of short-wave diathermy had no effect.

Phenylbutazone $400 \mathrm{mg}$. three times daily was prescribed.

Result.-Three weeks later the patient needed no analgesics, slept well, and could work without much trouble, although exertion still caused some aching. The swelling did not decrease in size.

Case 3, a female laboratory worker aged 63, had a 6 months' history of pain over the left side of the chest, radiating towards the left shoulder.

Examination.--There was a hard, tender swelling over the left second costal cartilage. The overlying skin was intact and freely movable. Chest $x$ rays were negative and the erythrocyte sedimentation rate and leucocyte count were normal. There was no history of trauma to the area. The pain was exacerbated by coughing and deep breathing.

Treatment. -5 per cent. phenylbutazone ointment was massaged three or four times daily on the swelling.

Results.-After 5 weeks all pain had disappeared and only a slight swelling remained.

Case 4, a male labourer aged 41, had had a tender swelling on the chest for one year. There was no history of trauma to the area. Pain radiated from the tumour towards the left shoulder and was exacerbated by coughing.

Examination.-There was a hard, tender tumour over the left third costal cartilage. Chest $x$ rays were negative, the erythrocyte sedimentation rate was $8 \mathrm{~mm} . / 1 \mathrm{hr}$. and the leucocyte count and haemoglobin level were normal.

Treatment.-Various drugs and short-wave diathermy had been given without success.

Phenylbutazone $400 \mathrm{mg}$. twice daily was given for 2 weeks.

Result.-The pain and tenderness disappeared, and severe exertion caused no exacerbation of the pain, but the tumour remained unchanged.

\section{Discussion}

There is no specific treatment for Tietze's syndrome. Symptomatic measures which have been recommended include reassurance and analgesics (Düben, 1952; Motulsky and Rohn, 1953; Satani and Fujii, 1937; Parisel, 1951), rest and local heat (Deane, 1951), short-wave diathermy (Düben, 1952; Gukelberger, 1953), local counterirritants (Gukelberger, 1953), and roentgen irradiation (Laake, 1951). Partial or total resection of the involved cartilage has been performed in refractory cases (Beck and Berkheiser, 1954). In many cases, however, the results have not been satisfactory.

The results in our four cases indicate that physiotherapy, short-wave diathermy, and topical injections of local anaesthetics and cortisone derivatives are of little value. Rest was the most effective means of relieving the pain in the swollen costal cartilage.

Because three of the four patients were almost completely cured and one obtained significant improvement when treated with phenylbutazone three by mouth and one by topical inunction, this drug must be considered to be relatively effective. The fact that the symptoms of the Tietze's syndrome respond to treatment with phenylbutazone, perhaps gives some indication of the nature of this rare condition.

\section{Summary}

Four patients suffering from Tietze's syndrome which proved resistant to all kinds of therapy were treated with phenylbutazone, three orally and one locally with ointment. The results were unexpectedly good, three being cured and one (in whom the condition was of much longer duration) obtaining significant relief.

\section{REFERENCES}

Acharya, B. S. S. (1944). J. roy. Army med. Cps, 83, 148 (Two cases of Tietze's disease).

Beck, W. C., and Berkheiser, S. (1954). Surgery, 35, 762 (Prominent costal cartilages (Tietze's syndrome)).

Deane, E. H. W. (1951). Lancet, 1, 883 (Costal chondritis (Tietze's disease)).

Düben, W. (1952). Dtsch. med. Wschr., 77, 872 (Das Tietzesyndrom und seine differentialdiagnostische Bedeutung).

Gukelberger, M. (1953). Schweiz. med. Wschr., 83, 288 (Über das Syndrom von Tietze und seine differentialdiagnostische Bedeutung). 
Kayser, H. L. (1956). Amer. J. Med., 21, 982 (Tietze's syndrome).

Laake, H. (1951). Nord. Med., 46, 1793 (Tietzes syndrom).

Motulsky, A. G., and Rohn, R. J. (1953). J. Amer. med. Ass., 152, 504 (Tietze's syndrome, cause of chest pain and chest wall swelling).

Parisel, F. (1951). Acta orthop. belg., 17, 294 (Le syndrome de Tietze ou la tuméfaction douloureuse chondro-sternale).

Pasquali, E. (1950). Boll. Soc. triven. Chir., 4, xxii, issued with Acta chir. patav. (Tumefazione dolorosa delle cartilagini costali (sindrome di Tietze)).

Satani, H., and Fujii, S. (1937). Mitt. med. Akad. Kioto, 21, 1716 (Über 9 Fälle von Tietze'scher Krankheit).

Tietze, A. (1921). Berl. klin. Wschr., 58, 829 (Ueber eine eigenartige Häufung von Fällen mit Dystrophie der Rippenknorpel).

\section{La phénylbutazone dans le traitement du syndrome de} Tietze

RÉSUMÉ

On traita par la phénylbutazone quatre malades atteints de syndrome de Tietze, résistant à toute autre forme de thérapeutique; le médicament fut administré per os chez trois sujets et localement, en utilisant un onguent, chez un malade. Les résultats furent bons au dela de toute espérance: 3 malades furent guéris et le dernier (chez qui la maladie durait depuis plus longtemps) fut amélioré de façon significative.
La fenilbutazona en el tratamiento del síndrome de Tietze

\section{Sumario}

Cuatro enfermos con el síndrome de Tietze resistentes a todo tipo de terapía, fueron tratados con fenilbutazona, tres por vía oral y uno topicamente con pomada. Los resultados fueron inesperadamente buenos; tres enfermos fueron curados y uno (en él que la enfermedad había sido mucho más duradera) mejoró de manera significativa. 